\title{
Pulses of aphyric andesite dykes remobilising micrometre-sized crystal cargo at Tongariro, $\mathbf{N Z}$
}

C. LORMAND ${ }^{1 *}$, G. F. ZELLMER ${ }^{1}$, N. SAKAMOTO ${ }^{2}$, G.N. KILGOUR $^{3}$, A.S. PALMER ${ }^{4}$, H. YURIMOTO ${ }^{2}$, K. NÉMETH ${ }^{1}$, S. MEAD ${ }^{1}$, T. UBIDE ${ }^{5}$, Y. IIZUKA ${ }^{6}$ AND A. MOEBIS ${ }^{4}$

${ }^{1}$ Volcanic Risk Solutions, Massey University, Palmerston North, NZ (*correspondence: c.lormand@massey.ac.nz; g.f.zellmer@massey.ac.nz)

${ }^{2}$ Isotope Imaging Laboratory, Hokkaido University, Sapporo, Japan (naoya@ep.sci.hokudai.ac.jp)

${ }^{3}$ GNS Science, Wairakei Research Centre, Taupo, NZ

${ }^{4}$ SAE, Massey University, Palmerston North, NZ

${ }^{5}$ SEES, University of Queensland, Brisbane, QLD, Australia

${ }^{6}$ IES, Academia Sinica, Nankang, Taipei, Taiwan

The Tongariro Volcanic Centre $(\mathrm{TgVC})$, located at the southern end of the Taupo Volcanic Zone in New Zealand, has produced historical explosive eruptions of different eruptive styles. To understand magma ascent processes and their associated timescales, the textures and compositions of microlites and micro-phenocrysts from glass shards (c. $12 \mathrm{ka}$ BP to 1996 AD) were studied, associated with eruptions ranging from Strombolian to Plinian in style. High resolution SEM and SIMS images, including chemical maps of the micro-phenocrysts $(<100 \mu \mathrm{m})$ display a variety of disequilibrium textures and compositions, and indicate multiple events of magma recharge and mixing suggesting an antecrystic origin. Crystal size distribution of 60,000 microlites $(<30 \mu \mathrm{m})$ of plagioclase and pyroxene were generated from BSE images using a semi-automatic method [1]. Combined with a well-constrained growth rate, crystallisation times were derived. Microlites started crystallising 2 to 4 days before the eruption, regardless of eruption style. Microlites formed between mid-crustal depths and the surface, at unusually high temperature $\left(\sim 1076{ }^{\circ} \mathrm{C}\right)$ and low water contents $(\sim 0.4 \mathrm{wt} \%)$ for intermediate arc magmas. The data imply ascent rates of up to $9 \mathrm{~cm} \mathrm{~s}^{-1}$ prior to shallow water exsolution. After complete water exsolution, vent exit velocities are not expected to exceed $27 \mathrm{~m} \mathrm{~s}^{-1}$, i.e. too slow to feed explosive eruptions characterised by supersonic exit velocities. We conclude that micro-crystalline cargos from previous dyke intrusions of aphyric melts were remobilised by magmas that funnelled into narrow cylinders near the surface, allowing acceleration and explosive eruptions of tephras entraining micro-antecrysts. We find that explosivity is controlled by conduit geometry, with narrower conduits resulting in more explosive eruptions.

[1] Lormand et al. (2018) Microsc. \& Microan. 24, 667-675. 